\title{
Penerapan Metode Simple Additive Weighting Untuk Merekomendasikan Penentuan Supplier Bahan Baku Kertas
}

\author{
Ria Agustriani ${ }^{1^{*}}$, Lis Utari $^{2}$ \\ ${ }^{1}$ STIKOM Binaniaga/Sistem Informasi \\ Email: ria_ag92@gmail.com \\ ${ }^{2}$ STIKOM Binaniaga/Teknik Informatika \\ Email: lis_utari@yahoo.com
}

\begin{abstract}
Information technology that continues to grow now provides a lot of convenience to humans, including in the service / production business. The parts that support the service I production business continue to be developed, so that more benefits for the organizers. One part that continues to be examined is the determination of the supplier of goods for the production company, because a good supplier will not only maximize the cooperation relationship, but also supply quality raw materials, and provide convenience in the process of supplying goods. Development research for selecting the best suppliers will be recommended to operational managers with a web-based system and using the SAW method (Simple Additive Weighting) using the 5 criteria set by PT. Topcom Multipap and 2 other criteria obtained from distributing questionnaires at PT. Topcom Multipap , so that 7 criteria are obtained, namely payment, quality, delivery, price, packing, flexibility and service. The system is used by 2 users (users), namely operational and purchasing managers, where the output of the system is in the form of supplier ranking previously assessed by the purchasing department based on previous raw material orders. The system was tested with 18 supplier data as training and testing data in Topcom Multipap, with the highest ranking results, namely the first rank obtained by PT. Main Blessing with a value of 32.22 so that PT. Berkat Utama is a supplier of paper raw materials which was chosen as the best supplier for PT.Topcom Multipap. The test results of all aspects of system feasibility assessment conducted through questionnaires were $73 \%$ where the lowest percentage was in the aspect of use assessment which was $60 \%$ while the highest was in the aspect of system quality assessment which was $86 \%$.
\end{abstract}

Keywords: Supplier Recommendations, PHP, Web Applications, Prototypes, SAW.

\begin{abstract}
ABSTRAK
Teknologi Informasi yang terus berkembang saat ini memberikan banyak kemudahan pada manusia termasuk dalam bisnis jasa/produksi. Bagian-bagian yang mendukung bisnis jasa/produksi terus dikembangkan, sehingga semakin memberikan keuntungan bagi penyelenggara. Salah satu bagian yang terus diteliti adalah penentuan Supplier barang bagi perusahaan produksi, karena Supplier yang baik tidak hanya akan memaksimalkan hubungan kerjasama, tetapi juga memasok barang bahan baku yang berkualitas, serta memberikan kemudahan dalam proses pemasokan barang. Penelitian pengembangan untuk penyeleksian supplier terbaik ini akan direkomendasikan kepada manager operasional dengan sistem berbasis web dan menggunakan metode SAW (Simple Additive Weighting) menggunakan 5 kriteria yang telah tentukan oleh PT.Topcom Multipap dan 2 kriteria lainnya yang diperoleh dari penyebaran kuesioner di PT.Topcom Multipap, sehingga di diperoleh 7 kriteria yaitu pembayaran, kualitas, pengiriman, harga, packing, flesibilitas dan layanan. Sistem tersebut digunakan oleh 2 user (pengguna) yaitu manager operasional dan purchasing dimana hasil output sistem tersebut berupa perangkingan supplier yang sebelumnya dinilai oleh bagian purchasing berdasarkan pemesanan bahan baku sebelumnya. Sistem di uji dengan data 18 supplier sebagai data training dan testing di Topcom Multipap, dengan hasil nilai rangking
\end{abstract}


tertinggi yaitu Rangking pertama diperoleh PT. Berkat Utama dengan nilai 32,22 sehingga PT. Berkat Utama adalah supplier bahan baku kertas yang terpilih sebagai supplier terbaik untuk PT.Topcom Multipap. Hasil uji keseluruhan aspek penilaian kelayakan sistem yang di lakukan melalui angket yaitu 73\% dimana persentase terendah pada aspek penilaian penggunaan yaitu $60 \%$ sedangkan tertinggi pada aspek penilaian kualitas sistem yaitu $86 \%$.

Kata Kunci: Rekomendasi supplier, php, web aplikasi, prototipe, SAW (Simple Additive Weighting)

\section{PENDAHULUAN}

PT. Topcom Multipap adalah perusahaan berbentuk Perseroan Terbatas (PT) yang bergerak dibidang percetakan kertas komputer (Continous Form), melayani pembuatan mulai dari desain/layout hingga cetak untuk produk-produk dokumen dengan bahan continuous form seperti amplop gaji, tagihan rumah sakit, delivery order, faktur, kop surat, purchase order dan tanda terima.

Persaingan internal perusahaan yang saat ini sangat kompetitif menyebabkan ketepatan penentuan supplier sebagai pihak penyedia bahan baku sangat berperan penting dalam menentukan kualitas produk, menjamin ketersediaan barang pasokan yang dibutuhkan dan kelancaran proses penyaluran barang di suatu perusahaan. Untuk menghasilkan profit yang maksimal dapat dilakukan dengan cara meningkatkan kualitas produk sehingga perusahaan dapat berjalan dengan lancer, sehingga kinerja supplier atau pemasok akan mempengaruhi performansi atau kinerja perusahaan.

PT.Topcom Multipap mendapat pasokan dari beberapa supplier yang menjual bahan baku yang sama sehingga pihak perusahaan kesulitan dalam memberikan penilaian terhadap supplier, karena masih bersifat konvesional. Penilaian terhadap supplier masih diukur dari pendapat, perasaan dan perilaku masing-masing supplier. Pihak perusahaan awalnya 5 kriteria yaitu 1 . harga, 2. kualitas, 3. pengiriman, 4.syarat pembayaran 5. Layanan, setelah dipertimbangkan maka menjadi 7 variabel yang digunakan

A. Rumusan Masalah

Penilaian PT. Topcom Multipap terhadap supplier belum optimal karena hanya diukur berdasarkan pendapat, perasaan dan perilaku masing-masing supplier, sehingga memunculkan beberapa permasalahan seperti kualitas bahan baku, keterlambatan waktu supplier dalam mengirim bahan baku kertas yang menyebabkan stok bahan baku kertas pun menjadi kosong, harga bahan baku, cara pembayaran yang dilakukan, kurangnya layanan dalam menerima keluhan dari pelanggan dan supplier agak lambat memberi solusi kepada pelanggan.

Untuk mengatasi permasalahan tersebut maka diperlukan sebuah sistem informasi yang dapat mendukung pengambilan keputusan perusahaan dalam memilih supplier yang terbaik dengan menentukan kriteria yang tepat dan akurat.

Berdasarkan uraian diatas, maka dapat diidentifikasi masalah dalam penentuan supplier yaitu :

1. Belum digunakan kriteria dan bobot kriteria dalam penentuan supplier bahan baku kertas pada PT. Topcom Multipap.

2. Sulit menentukan prioritas supplier bahan baku kertas pada PT.Topcom Multipap

B. Maksud dan Tujuan Penelitian

1. Maksud

Maksud penelitian ini adalah menerapkan Simple Additive Weighting (SAW) untuk merekomendasikan penentuan supplier bahan baku kertas yang tepat pada PT. Topcom Multipap. 


\section{Tujuan}
a. Untuk mengetahui kriteria dan bobot kriteria yang dapat digunakan dalam penentuan supplier bahan baku kertas pada PT. Topcom Multipap.
b. Untuk menentukan prioritas supplier bahan baku kertas pada PT.Topcom Multipap.

\section{Tinjauan Pustaka}

Penelitian yang menjadi acuan penulisan adalah penelitian yang dilakukan oleh Radiant V. Imbar, Doro Edi, Kevin Masli ( 2016) dalam jurnal "Sistem Pendukung Keputusan Penerima Beasiswa Dengan Metode Simple Additive Weighting (Studi Kasus : Fakultas Teknologi Informasi U.K. Maranatha)"

Pada penelitian tersebut permasalahan yang dibahas adalah mengenai pendaftaran dan penerimaan beasiswa yang belum terkomputerisasi, sehingga kesulitan dalam melakukan pendaftaran maupun melihatdata mahasiswa yang mendaftar. Hasil penelitian ini adalah suatu sistem pendukung keputusan yang akan diimplementasikan di lingkup Fakultas Teknologi Informasi Universitas Kristen Maranatha. Sistem tersebut berupa Aplikasi dengan lihat data pendaftaran yang dapat digunakan untuk mengelola dan melihat perolehan poin pendaftaran beasiswa, Aplikasi dengan fitur info poin dan export dapat digunakan untuk melihat informasi mahasiswa yang mendaftar beasiswa, Aplikasi dengan fitur generate SAW berguna untuk pejabat struktural dalam mendukung pengambilan keputusan penentuan mahasiswa yang berhak mendapatkan beasiswa. Model yang digunakan dalam sistem pendukung keputusan ini adalah SAW. SAW ini dipilih karena dapat menentukan nilai bobot untuk setiap atribut, kemudian dilanjutkan dengan proses perankingan yang akan menyeleksi alternatif terbaik dari sejumlah alternatif, dalam hal ini alternatif yang dimaksud adalah yang berhak menerima beasiswa berdasarkan kriteria-kriteria yang ditentukan yaitu Gaji Orang Tua, Jumlah Tanggungan Orang Tua, Pekerjaan Orang Tua, Jarak Rumah Siswa ke Sekolah, Kepemilikan Kendaraan. Dengan metode perankingan tersebut, diharapkan penilaian akan lebih tepat karena didasarkan pada nilai kriteria dan bobot yang sudah ditentukan sehingga akan mendapatkan hasil yang lebih akurat terhadap siapa yang akan menerima beasiswa.

\section{METODE}

Metode SAW adalah Salah satu metode penyelesaian masalah dari Fuzzy Multiple Attribute Decision Making ( FMADM ) untuk mencari alternatif optimal dari sejumlah alternatif dengan kriteria tertentu. Definisi Metode Simple Additive Weighting $(S A W)$ sering juga dikenal istilah metode penjumlahan terbobot. Konsep dasar metode SAW adalah mencari penjumlahan terbobot dari rating kinerja pada setiap alternatif pada semua atribut (Fishburn,1967)(MacCrimmon,1968). Metode ini membutuhkan proses normalisasi matriks keputusan $\mathrm{X}$ ke suatu skala yang dapat diperbandingkan dengan semua rating alternatif yang ada. Formula untuk melakukan normalisasi tersebut adalah sebagai berikut (Kusumadewi, Harjoko, dan Wardoyo. 2006):

$$
r_{i j}= \begin{cases}\frac{x_{i j}}{M^{A X}\left(x_{i j}\right)} & \text { Jika jadalah atribut keuntungan (benefit) } \\ \frac{M I N}{i}\left(x_{i j}\right) & \text { Jika adalah atribut biaya (cost) }\end{cases}
$$

Dimana :

rij $=$ rating kinerja ternormalisasi dari alternatif $\mathrm{Ai}(\mathrm{i}=, 2, \ldots, \mathrm{m})$ Maxi= nilai maksimum dari setiap baris dan kolom.

$\min =$ nilai minimum dari setiap baris dan kolom. $x i j=$ baris dan kolom dari matriks.

Formula untuk mencari nilai preferensi untuk setiap alternatif (Vi) diberikan sebagai:

$$
V_{i}=\sum_{j=1}^{n} w_{j} r_{i j}
$$


Dimana :

$\mathrm{Vi} \quad=$ Nilai akhir dari alternatif $\mathrm{Wi}=$ Bobot yang telah ditentukan

Rij = Normalisasi matriks.

Nilai Vi yang lebih besar mengindikasikan bahwa aternatif Ai lebih terpilih. (Kusumadewi, Harjoko, dan Wardoyo.2006).

Langkah Penyelesaian SAW sebagai berikut :

1. Menentukan kriteria-kriteria yang akan dijadikan acuan dalam pengambilan keputusan, yaitu $\mathrm{Ci}$.

2. Menentukan rating kecocokan setiap alternatif pada setiap kriteria.

3. Membuat matriks keputusan berdasarkan kriteria (Ci), kemudian melakukan normalisasi matriks berdasarkan persamaan yang disesuaikan dengan jenis atribut (atribut keuntungan ataupun atribut biaya) sehingga diperoleh matriks ternormalisasi $\mathrm{R}$

4. Hasil akhir diperoleh dari proses perankingan yaitu penjumlahan dari perkalian matriks ternormalisasi $\mathrm{R}$ dengan vektor bobot sehingga diperoleh nilai terbesar yang dipilih sebagai alternatif terbaik (Ai) sebagai solusi.

Kelebihan dari metode simple additive weighting dibanding dengan model pengambil keputusan lainnya terletak pada kemampuannya untuk melakukan penilaian secara lebih tepat karena didasarkan pada nilai kriteria dan bobot preferensi yang sudah ditentukan, selain itu SAW juga dapat menyeleksi alternatif terbaik dari sejumlah alternatif yang ada karena adanya proses perangkingan setelah menentukan bobot untuk setiap atribut (Kusumadewi, Harjoko, dan Wardoyo. 2006).

\section{HASIL DAN PEMBAHASAN}

\section{Hasil Penelitian}

A. Hasil Tampilan

\section{Hasil Tampilan Beranda PT. Topcom Multipap}

Beranda (halaman utama) adalah halaman pertama yang dibuka ketika user berhasil login atau masuk ke dalam sistem dan pada halaman utama tersebut menyediakan menu yang berbeda sesuai kebutuhan user atau level user login.

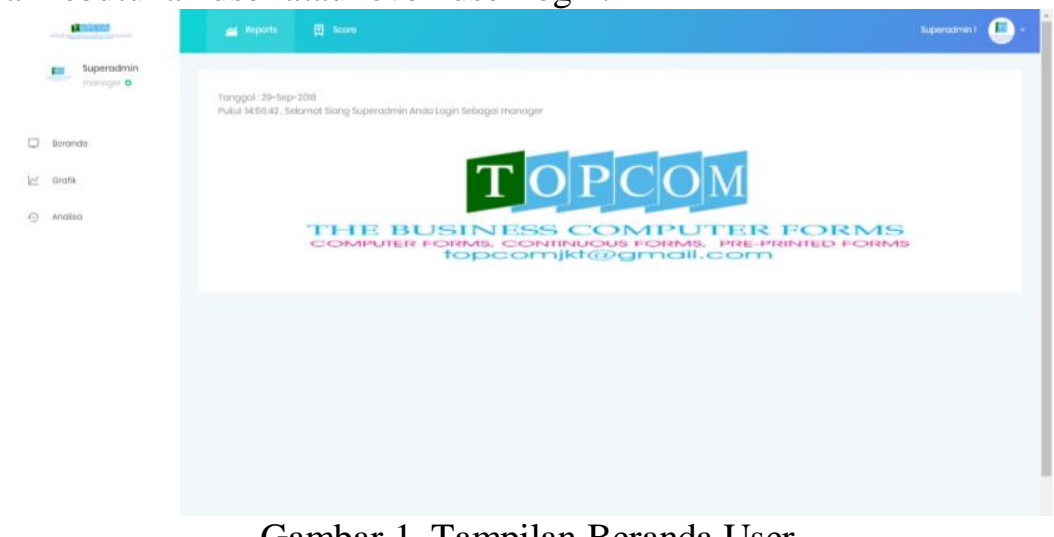

Gambar 1. Tampilan Beranda User

\section{Hasil Tampilan Input Data Supplier}

Input data supplier yaitu penginputan informasi supplier yang sudah bekerja sama dengan PT Topcom multipap dimana data supplier tersebut akan dinilai berdasarkan kriteria yang sudah tersedia. 


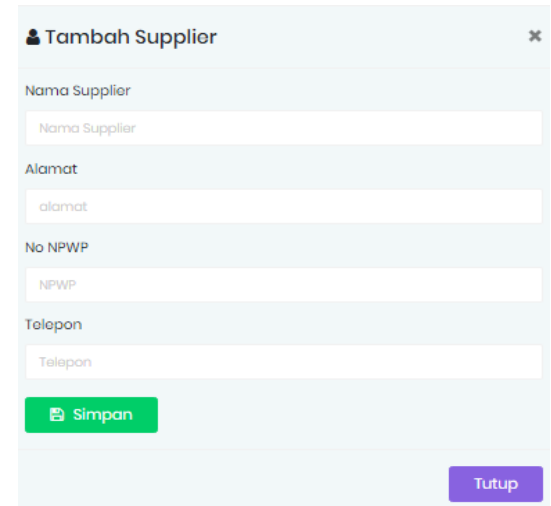

Gambar 2. Input Data Supplier

\section{Hasil Tampilan Edit Data Supplier}

Edit data supplier yaitu pembaharuan data supplier yang digunakan apabila terjadi kesalahan penginputan data supplier.

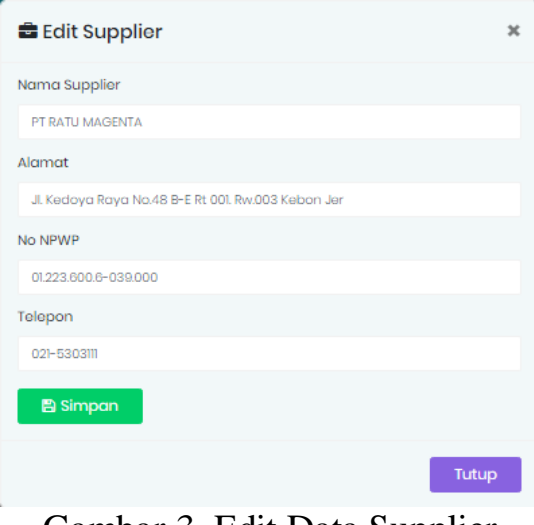

Gambar 3. Edit Data Supplier

\section{B. Hasil Tampilan Output}

\section{Hasil Tampilan Penilaian Supplier}

Penilaian supplier yaitu dimana setiap supplier diberikan penilaian pada setiap kriteria yang sudah tersedia dan nilai yang sudah tersedia kemudian penilaian tersebut digunakan untuk berhitung dengan menggunakan metode SAW di dalam sistem.

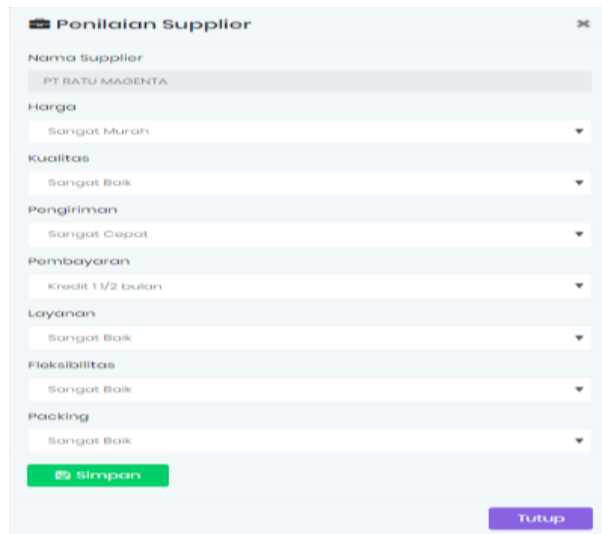

\section{Gambar 4. Penilaian Supplier}

\section{Hasil Tampilan Proses Perangkingan}

Proses perangkingan yaitu proses perhitungan dengan metode SAW berdasarkan pada penilaian setiap supplier yang sudah dilakukan dimana hasil proses tersebut akan menghasilkan perangkingan supplier bahan baku terbaik. 


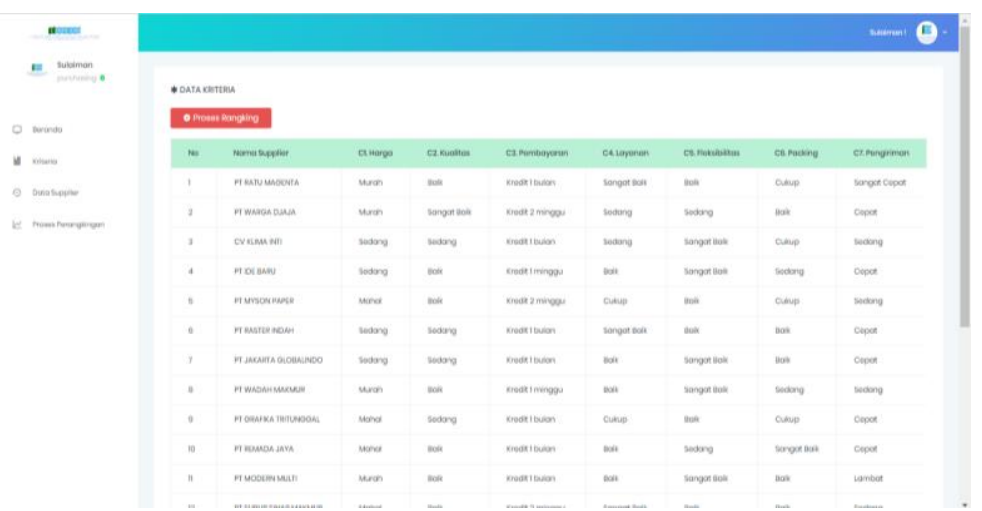

Gambar 5. Proses Perangkingan

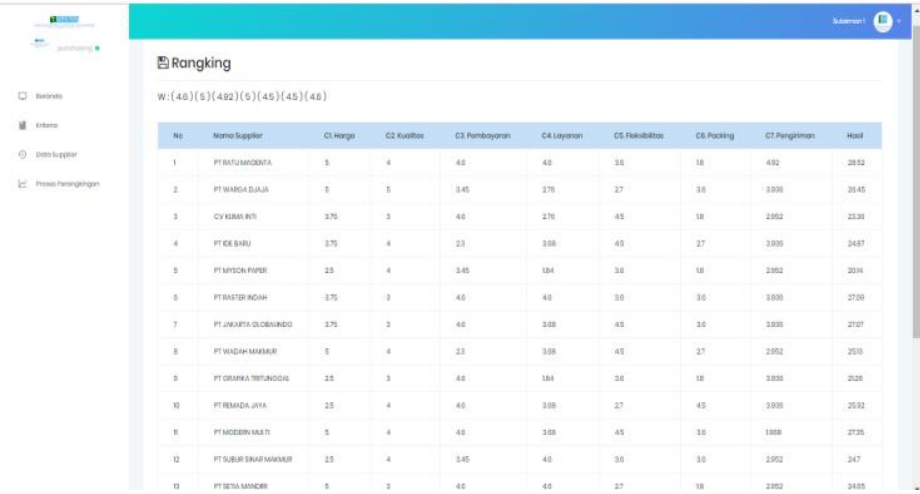

Gambar 6. Hasil Proses Perangkingan

\section{Hasil Tampilan Grafik Perangkingan}

Grafik perangkingan yaitu informasi perangkingan secara visual yang digambarkan dengan grafik batang untuk kebutuhan laporan kepada manager operasional dari hasil proses perangkingan.

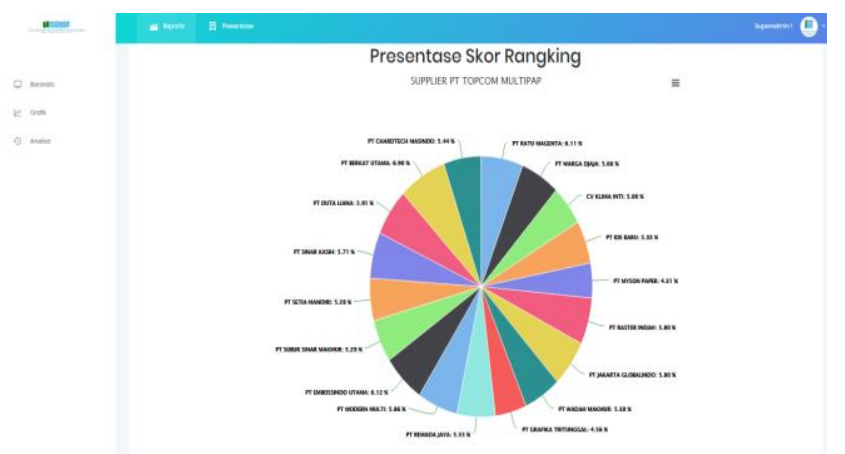

Gambar 7.Hasil Proses Grafik Perangkingan

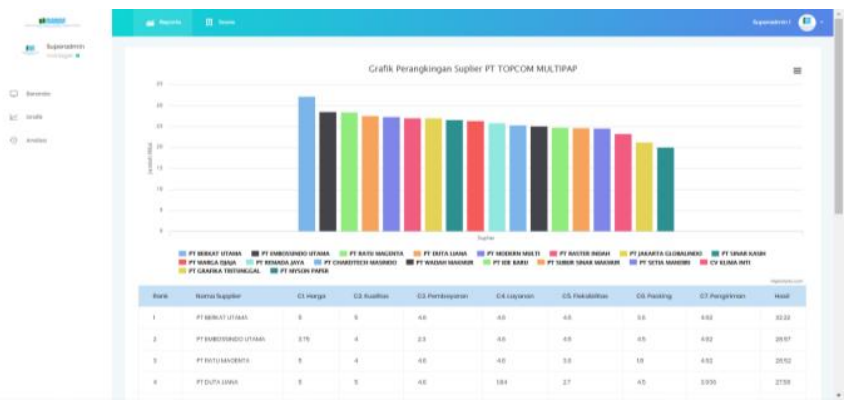

Gambar 8. Grafik Laporan Perangkingan 


\section{Pembahasan}

Aplikasi ini dilihat dan coba digunakan oleh bagian purchasing dan manager operasional dengan menilai apakah sistem ini sudah sesuai dengan kebutuhan yang ada di PT. Topcom Multipap tersebut, adapun penilaian yang dilakukan dengan cara menguji aplikasi yang sudah dibuat dan penilaianpun dilakukan dengan menggunakan metode penyebaran kuesioner kepada Ahli sistem informasi. dan pengguna yaitu bagian purchasing, bagian produksi, manager keuangan dan manager operasional, berikut penilaian kuesioner tersebut :

\section{A. Kuisioner Untuk Ahli Sistem Informasi}

Merupakan tahapan pengujian untuk memvalidasi sistem yang dilakukan oleh para ahli .pengujian ini dilakukan guna mengoreksi kesalahan - kesalahan dan kekurangan yang ada pada sistem, ahli sistem informasi juga memberikan pendapat dan saran serta rekomendasi untuk memperbaiki sistem yang sedang dikembangkan agar menjadi lebih baik. Pengujian sistem melibatkan 1 ahli sistem informasi, berikut adalah hasil dari kuesioner untuk ahli sistem informasi :

\section{Spesifikasi uji membuka aplikasi}

Tabel 2. Kuisioner untuk Ahli Sistem Informasi

\begin{tabular}{|c|c|c|c|c|}
\hline \multirow[t]{2}{*}{ No. } & \multirow[t]{2}{*}{$\begin{array}{l}\text { Aktivitas/ } \\
\text { menu }\end{array}$} & \multirow[t]{2}{*}{ Hasil yang diharapkan } & \multicolumn{2}{|c|}{$\begin{array}{l}\text { Taraf } \\
\text { ketercapaian }\end{array}$} \\
\hline & & & Ya & Tidak \\
\hline 1. & \begin{tabular}{|l|}
$\begin{array}{l}\text { Membuka } \\
\text { sistem }\end{array}$ \\
\end{tabular} & Menampilkan halaman login & $\sqrt{ }$ & \\
\hline 2. & $\begin{array}{l}\text { User } \\
\text { melakukan } \\
\text { login }\end{array}$ & $\begin{array}{l}\text { Menampilkan halaman utama } \\
\text { penentuan supplier sesuai } \\
\text { kebutuhan pengguna }\end{array}$ & $\sqrt{ }$ & \\
\hline
\end{tabular}

\section{Spesiikasi uji halaman penentuan supplier terbaik}

Tabel 3. Kuisioner untuk Ahli Sistem Informasi

\begin{tabular}{|c|c|c|c|c|}
\hline \multirow[t]{2}{*}{ No. } & \multirow[t]{2}{*}{$\begin{array}{l}\text { Aktivitas/ } \\
\text { menu }\end{array}$} & \multirow{2}{*}{ Hasil yang diharapkan } & \multicolumn{2}{|c|}{$\begin{array}{c}\text { Taraf } \\
\text { ketercapaian }\end{array}$} \\
\hline & & & Ya & Tidak \\
\hline 1 & $\begin{array}{l}\text { Halaman } \\
\text { utama }\end{array}$ & $\begin{array}{l}\text { yser dapat melihat menu kebutuhan } \\
\text { di halaman utama setelah } \\
\text { melakukan login. }\end{array}$ & $\checkmark$ & \\
\hline \multirow{2}{*}{2} & \multirow{2}{*}{$\begin{array}{l}\text { Proses input } \\
\text { nilai }\end{array}$} & $\begin{array}{l}\text { user dapat menginput nilai } \\
\text { berdasarkan kriteria }\end{array}$ & $\sqrt{ }$ & \\
\hline & & $\begin{array}{l}\text { yser dapat memilith kriteria untuk } \\
\text { diberikan nilai. }\end{array}$ & $\sqrt{ }$ & \\
\hline 3 & $\begin{array}{l}\text { Proses input } \\
\text { supplier }\end{array}$ & $\begin{array}{l}\text { user dapat melakukan input } \\
\text { informasi supplier di dalam sistem }\end{array}$ & $\sqrt{ }$ & \\
\hline 4 & $\begin{array}{l}\text { Proses } \\
\text { penilaian }\end{array}$ & $\begin{array}{l}\text { user dapat menginput peniaian } \\
\text { supplier berdasarkan nilai dan } \\
\text { kriteria yang sudah ditentukan }\end{array}$ & $\checkmark$ & \\
\hline \multirow{2}{*}{5} & \multirow[t]{2}{*}{$\begin{array}{l}\text { Proses } \\
\text { perangkingan }\end{array}$} & $\begin{array}{l}\text { user dapat melihat keterangan } \\
\text { penilaian supplier berdasarkan input } \\
\text { penilaian di halaman proses } \\
\text { perangkingan }\end{array}$ & $\checkmark$ & \\
\hline & & $\begin{array}{l}\text { setelah menekan tombol proses } \\
\text { perangkingan user dapat masuk ke } \\
\text { halaman hasil perangkingan }\end{array}$ & $\sqrt{ }$ & \\
\hline 6 & $\begin{array}{l}\text { Grafik } \\
\text { perangkingan }\end{array}$ & $\begin{array}{ll}\text { user dapat melihat } & \text { grafik } \\
\text { perangkingan dan mencetak } \\
\text { perangkingan di dalam sistem }\end{array}$ & $\sqrt{ }$ & \\
\hline 7 & $\begin{array}{l}\text { Analisa } \\
\text { perangkingan }\end{array}$ & $\begin{array}{l}\text { user dapat melihat analisa } \\
\text { perhitungan hasil perangkingan di } \\
\text { halaman analisa perangkingan }\end{array}$ & $\sqrt{ }$ & \\
\hline
\end{tabular}

Data yang diperoleh melalui instrumen penelitian kepada ahli sistem ini di uji dengan menggunakan statistik deskriptif kuantitatif dimaksudkan untuk menggambarkan karakteristik data pada masing-masing variabel. Hasil presentase digunakan sebagai jawaban atas kelayakan dari aspek-aspek yang diteliti dengan hasil angket dijumlahkan berdasarkan point jawaban lalu dibandingkan dengan jumlah yang diharapkan untuk memperoleh presentase berikut hasil kelayakan presentase dalam penelitian ini :

Presentase Kelayakan $\%=2+7=9 \times 100=100 \%$

Pengumpulan data angket kepada ahli sistem diketahui bahwa perolehan rata-rata skor presentase kelayakan yaitu $100 \%$. Berdasarkan presentase kelayakan maka dapat 
disimpulkan bahwa sistem sangat layak dikembangkan mengenai skala penilaian dapat dilihat pada tabel kelayakan (Tabel 4)

Tabel 4. Persentase Kelayakan Menurut Arikunto

\begin{tabular}{|c|c|}
\hline Presentase Pencapaian & Interpretasi \\
\hline$<21 \%$ & Sangat Tidak Layak \\
\hline $21 \%-40 \%$ & Tidak Layak \\
\hline $41 \%-60 \%$ & Cukup layak \\
\hline $61 \%-80 \%$ & Layak \\
\hline $81 \%-100 \%$ & Sangat Layak \\
\hline
\end{tabular}

\section{B. Kuisioner Untuk Pengguna}

Digunakan untuk memperoleh data yang digunakan untuk menganalisa kualitas sistem yang telah dibuat. Pengujian untuk pengguna melibatkan bagian purchasing, bagian produksi, manager keuangan dan manager operasional. Adapun pertanyaan tersebut dapat dilihat pada tabel 5 .

Tabel 5. Kuisioner Untuk Pengguna

\begin{tabular}{|c|c|c|c|c|c|c|}
\hline \multirow[t]{2}{*}{ No } & \multirow[t]{2}{*}{ Knitenia } & \multicolumn{5}{|c|}{ Pijihan } \\
\hline & & SS & $\mathbf{S}$ & CS & TS & STS \\
\hline 1 & Saya mendapat datalengkap sesuaikebutuhan pekejaan & & & & & \\
\hline 2 & $\begin{array}{l}\text { Informasi yang saya dapatkan sesuai dengan data yang } \\
\text { sebenamya }\end{array}$ & & & & & \\
\hline 3 & $\begin{array}{l}\text { Saya dapat mengandalkan data yang didapatkan dalam } \\
\text { memenuhi kebutuhan informasi untuk bekeja }\end{array}$ & & & & & \\
\hline 4 & $\begin{array}{l}\text { Data yang saya dapatkan adalah informasi yang terkinidan } \\
\text { selalu diperbahani }\end{array}$ & & & & & \\
\hline 5 & $\begin{array}{l}\text { Saya dapat menggunakan sistem dan menubahdata yang lain } \\
\text { menggunakan sistem yang ada }\end{array}$ & & & & & \\
\hline 6 & $\begin{array}{l}\text { Saya dapat beninteraksidengan sistem dan instansi yanglain } \\
\text { menggunakan sistem yang ada }\end{array}$ & & & & & \\
\hline 7 & $\begin{array}{l}\text { Saya tidakpeniu waktu lama mendapatkan informasi setelah } \\
\text { mengakses sistem }\end{array}$ & & & & & \\
\hline 8 & $\begin{array}{l}\text { Sistem membenkan fasüitas perbaikan jika tepjadikegagalan } \\
\text { sistem }\end{array}$ & & & & & \\
\hline 9 & Saya merasa nyaman dan mudah dalam menggunakan sistem & & & & & \\
\hline 10 & $\begin{array}{l}\text { Saya dapat dengan mudah mengertibahasa yang dimaksud } \\
\text { oleh sistem }\end{array}$ & & & & & \\
\hline 11 & $\begin{array}{l}\text { Saya merasa aman dalam mengakses atau menginm data } \\
\text { melalui sistem }\end{array}$ & & & & & \\
\hline 12 & $\begin{array}{l}\text { Sistem membenkan beberapa masukan yangmungkin } \\
\text { berguna bagipekerjaan saya }\end{array}$ & & & & & \\
\hline 13 & $\begin{array}{l}\text { Sistem membenkan tanggapan sesuaidengan apa yangsaya } \\
\text { lakukan }\end{array}$ & & & & & \\
\hline 14 & Saya dapat mengakses sistem setiap waktu & & & & & \\
\hline 15 & $\begin{array}{l}\text { Selama saya bekenja frekuensi pengguna terhadap sistem } \\
\text { cukup tinggi }\end{array}$ & & & & & \\
\hline 16 & Saya puas dengandata dan informasi yang saya dapat & & & & & \\
\hline 17 & Saya puas dengan sistem yang ada & & & & & \\
\hline 18 & $\begin{array}{l}\text { Saya dapat menyelesaikan pekenjaan lebih cepat dengan } \\
\text { menggunakan sistem }\end{array}$ & & & & & \\
\hline 19 & Kinejia saya lebih baik dengan menggunakan sistem & & & & & \\
\hline 20 & Saya lebih efektif dalam bekerja dengan menggunakan sistem & & & & & \\
\hline
\end{tabular}

Data yang diperoleh melalui instrumen penelitian ini di uji dengan menggunakan statistik deskriptif kuantitatif dimaksudkan untuk menggambarkan karakteristik data pada masing-masing variabel. Hasil presentase digunakan sebagai jawaban atas kelayakan dari aspek-aspek yang diteliti dengan hasil angket dijumlahkan berdasarkan point jawaban lalu dibandingkan dengan jumlah yang diharapkan untuk memperoleh presentase berikut hasil kelayakan presentase dalam penelitian ini :

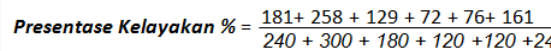

kelayakan sistem berdasarkan aspek penilaian beserta presentase setiap aspek penilaian dirincikan pada tabel 6 berikut : 
Tabel 6. Persentase Kelayakan

\begin{tabular}{|c|l|c|c|c|}
\hline No & \multicolumn{1}{|c|}{ Aspek Penilaian } & $\begin{array}{c}\text { Skor } \\
\text { Observasi }\end{array}$ & $\begin{array}{c}\text { Skor yang } \\
\text { diharapkan }\end{array}$ & Kelayakan \\
\hline 1 & Kualitas Informasi & 181 & 240 & $75 \%$ \\
\hline 2 & Kualitas Sistem & 258 & 300 & $86 \%$ \\
\hline 3 & Kualitas Layanan & 129 & 180 & $71,67 \%$ \\
\hline 4 & Penggunaan & 72 & 120 & $60 \%$ \\
\hline 5 & Kepuasan Pengguna & 76 & 120 & $63,33 \%$ \\
\hline 6 & Keuntungan Bersih & 161 & 240 & $67,08 \%$ \\
\hline \multicolumn{2}{|c|}{ Jumlah } & 876 & 1200 & $73,00 \%$ \\
\hline
\end{tabular}

Dari hasil pengumpulan data diketahui bahwa perolehan rata-rata skor presentase kelayakan yaitu $73,00 \%$ dimana perolehan skor tertinggi yaitu $86 \%$ terdapat pada kualitas sistem dan skor paling rendah yaitu penggunaan yaitu $60 \%$. Berdasarkan presentase kelayakan maka dapat disimpulkan bahwa sistem layak dikembangkan, skala penilaian dapat dilihat pada tabel kelayakan di atas.

\section{SIMPULAN DAN SARAN}

\section{A. Kesimpulan}

Berdasarkan pada hasil penelitian pada penjelasan terdahulu dapat ditarik beberapa kesimpulan sebagai berikut :

1. Kriteria serta bobot yang digunakan pada sistem ini yaitu harga $=5$, kualitas $=5$, pengiriman $=$ 4.92 , syarat pembayaran $=4.6$, layanan $=4.6$, fleksibilitas $=4.5$ dan packing $=4.5$ sehinggga dapat memaksimalkan dalam pemilihan supplier untuk direkomendasikan.

2. Pada hasil perhitungan di dalam sistem penentuan supplier terbaik dalam perangkingan berdasarkan pada kriteria yang telah ditentukan sistem dapat melakukan perangkingan pada tiap-tiap supplier yang sudah mempunyai nilai dan menghasilkan urutan supplier terbaik untuk direkomendasikan menggunakan perhitungan SAW (Simple Additive Weighting).

\section{B. Saran}

Saran dalam penelitian tentang sistem penentuan supplier bahan baku kertas pada PT. Topcom Multipap adalah sebagai berikut :

1. Penelitian hanya menggunakan perhitungan SAW (Simple Additive Weighting), untuk perbandingan dapat menggunakan metode lainnya seperti AHP, Fuzzy Tsukamoto, Weighted Product dan lain - lain.

2. Kriteria penilaian bisa di tambah beberapa kriteria penting lainnya yang menyangkut pemilihan supplier untuk mendapatkan hasil yang kompleks.

3. Interval masing - masing kriteria dapat di rubah sesuai kebutuhan.

\section{DAFTAR RUJUKAN}

A. G. Anto, H. Mustafidah, and A. Suyadi, "Sistem Pendukung Keputusan Penilaian Kinerja Karyawan Menggunakan Metode SAW ( Simple Additive Weighting )," Juita, vol. III, no. November, pp. 193-200, 2015.

Arikunto, S. 2006. Prosedur Penelitian Suatu Pendekatan Praktik, Jakarta : Rineka Cipta

Arikunto, S. 2009. Manajemen Penelitian, Jakarta : Rineka Cipta

A. Wahyu Oktaputra and E. Noersasongko, "Sistem Pendukung Keputusan Kelayakan Pemberian Kredit Motor Menggunakan Metode Simple Additive Weighting pada Perusahaan Leasing HD Finance," J. SPK Kelayakan Pemberian Kredit Mot., pp. 1-9, 2014.

David, Fred R, 2011. Strategic Management, Buku 1. Edisi 12 Jakarta

Fishburn, P.C. (1967) "A Problem-based Selection of Multi-Attribute Decision 
Jurnal IImiah Teknologi - Informasi dan Sains (TeknolS)

Volume 9 Nomor 1 Bulan Mei 2019 Hal. 43-52

p-ISSN : 2087-3891 dan e-ISSN : 2597-8918

Making Methods.” New Jersey : Blackwell Publishing

I. Safitrianingsih, "Penerapan Metode Simple Additive Weighting Untuk Seleksi Calon Peserta Gita Bahana Nusantara."

Kusrini. 2007. Konsep dan Aplikasi Sistem Pendukung Keputusan. Penerbit Andi, Yogyakarta

Kusumadewi, S. et al. 2006. Fuzzy Multi-Attribute Decision Making (FUZZY MADM). Graha Ilmu. Yogyakarta.

MacCrimmon,K.R.1968." Decision Making among Multiple Atribut Alternatives: a Survey and Consolidated Approach",

Pressman, Roger S. 2010. Rekayasa Perangkat Lunak Pendekatan Praktis ( Buku 1), Software Engineering : A Practitioner's Approach 7th. Yogyakarta

Pressman, Roger S. 2012. Rekayasa Perangkat Lunak. Yogyakarta: Andi

P. S. Hasugian, H. D. Hutahaean, and H. T. Sihotang, "Sistem Pendukung Keputusan Penentuan Guru Wali Kelas Pada SMP Negeri 19 Medan Dengan Menggunakan Metode Simple Additive Weighting," J. Inform. Pelita Nusant., vol. 2, no. 1, pp. 32-39, 2017.

Richard L. Levin 2011, Pengambilan Keputusan secara kuantitatif, Edisi Ketujuh,Rajawali Pers.

R. V. Imbar, D. Edi, and K. Masli, "Sistem Pendukung Keputusan Penerima Beasiswa Dengan Metode Simple Additive Weighting ( Studi Kasus di Fakultas Teknologi Informasi U.K. Maranatha)," J. Tek. Inform. dan Sist. Inf., vol. 2, no. 3, pp. 275-286, 2016.

Sugiyono, D. (2013). Metode penelitian pendidikan. Pendekatan Kuantitatif. Bandung

T. R. Adianto, Z. Arifin, D. M. Khairina, G. Mahakam, and G. Palm, "Sistem Pendukung Keputusan Pemilihan Rumah Tinggal Di Perumahan Menggunakan Metode Simple Additive Weighting (Saw) (Studi Kasus : Kota Samarinda), " Pros. Semin. Ilmu Komput. dan Teknol. Inf., vol. 2, no. 1, pp. 197-201, 2017.

Turban. dkk., 2005, Decision Support System and Intelligent System (Sistem Pendukung Keputusan dan Sistem Cerdas), Andi, Yogyakarta. 